\title{
Pengaruh Kebijakan Deviden Terhadap Kinerja Perusahaan Pertambangan Studi Empiris Pada Perusahan Manufaktur Di Bursa Efek Indonesia Tahun 2016-2018
}

\author{
Marselino Wau'), Yurmanius Waruwu ${ }^{2)}$ \\ ${ }^{1,2)}$ Prodi Manajemen, Sekolah Tinggi Ilmu Ekonomi Nias Selatan \\ Email : waumarselino561@gmail.com, yurmaniuswaruwu89@gmail.com
}

\begin{abstract}
Abstrak
Industri pertambangan merupakan industri penting bagi pemerintah pusat sebagai sumber pendanaan membiayai pembangunan negara, dimana kinerja perusahaan dalam hal ini industri telah menjadi bagian yang sangat penting di bidang akademisi dan praktisi. Perhatian peran tata kelola perusahaan dalam memoderasi hubungan antara kebijakan dividen dan kinerja harus terus ditingkatkan. Penelitian ini akan memperkaya kebijakan dividen dan perusahaan terhadap tata kelola. Penelitian ini bertujuan untuk mengetahui peran tata kelola perusahaan memoderasi hubungan antara kebijakan dividen dengan kinerja. Selain itu, studi ini juga melihat pengaruh kebijakan dividen dengan kinerja. Sampel penelitian ini direncanakan 21 perusahaan selama 3 tahun, diuji dengan menggunakan analisis regresi dimoderasi (MRA). Sebelum di uji dengan regresi kami akan melakukan beberapa analisis, seperti normalitas. Skor rata-rata masingmasing Variabel (ROA, DPR, PO, CA, dan CS). Dilanjutkan dengan menguji hipotesis, sehingga dapat diuji Interaksi kebijakan dividen dan tata kelola perusahaan dengan kinerja perusahaan.
\end{abstract}

\section{Kata kunci: Dividen, Corporate dan Kinerja Perusahaan.}

\section{PENDAHULUAN}

Kinerja perusahaan sebagian kinerja yang baik dan tidak, tentu masih belum memaksimalkan kesejahteraan para pemegang saham, Untuk melihat baik dan buruknya suatu perusahan dapat ditinjau dari kinerja perusahaan. kinerja perusahaan merupakan suatu gambaran kondisi keuangan perusahaan yang diukur dengan analisis rasio keuangan, serta mengetahui kemampuan keadaan keuangan perusahaan yang mencerminkan prestasi kerja dalam periode tertentu. Hal ini sangat penting agar sumber daya yang dimiliki dapat digunakan secara optimal.

Dalam menjalankan aktivitas perusahaan salah satu hal yang paling penting berupa dana yang digunakan, apakah akan memakai dana intern atau ekstern perusahaan dimana intern perusahaan merupakan dana yang berasal dana dari dalam perusahaan yaitu dana dari investasi pemilik perusahaan sedangkan dana ekstern yaitu pinjaman dari pihak lain atau bank dan juga berasal dari penjualan obligasi. Dari pemilihan penggunaan dana yang sesuai dengan berperan dalam kelangsungan perusahaan untuk menjalankan kegiatan perusahaan. pada saat ini terdapat berbagai macam indikator sebagai alat ukur dari suatu variabel, hal ini terkait dengan menentukan indikator sebagai alat ukur dari suatu variabel, karena harus mampu mereprestasikan variabel yang diukur secara tepat, sehingga secara ilmia bisa dipertanggungjawabkan kebenarannya sebagai indikator. Kinerja perusahaan juga dipakai mengukur seberapa efisien dan efektif kemampuan manajemen dalam mencapai tujuan perusahaan. perusahaan merupakan dimensi penting dalam penelitian manajemen. Kinerja perusahaan dibagi dalam beberapa kelompok defenisi, salah satunya dari pengelolaan perusahaan (Meixell dan Luoma, 2015).

Menurut Bringham dan Houston (2011) kebijakan dividen adalah "kebijakan mengenai berapa banyak laba saat ini yang akan dibayarkan sebagai dividen sebagai ganti dari dipertahankan untuk diinvestasikan kembali kedalam perusahaan". Perkembangan perusahaan pertambangan sangat memiliki dampak terhadap pembagian atau pembayaran dividen. Karena, dengan adanya pembayaran dividen maka para pemegang saham akan menyambung positif serta memberikan signaling atau berita baik dari perusahaan tersebut.

doi: https://doi.org/10.51544/jma.v6i2.2157

(C) 2021 Jurnal Mutiara Akuntansi. This is an open access article under the CC BY-SA license Website: http://e-journal.sari-mutiara.ac.id/index.php/JMA/ 
Tetapi, meskipun laba meningkat namun banyak perusahaan menjadi tidak lancar dalam membagikan dividen kepada pemegang sahamnya. Selain itu, penerapan corporate Dalam pengelolaan keuangan, seperti kebijakan dividen diperlukan corporate governance agar perilaku opportunistik manajemen bisa diminamalisasi sehingga biaya keagenan menurun dan akhinya meningkatkan kinerja perusahaan corporate govenance yang diukur dengan Dewan Komisaris independen dan Kepemilikan publik. Selain itu, dua variabel kontrol juga di gunakan yaitu umur perusahaan dan ukuran perusahaan.

Berdasarkan penjelasan di atas dapat di simpulkan bahwa penelitian interaksi kebijakan deviden dan corproate goivernance masih perlu di teliti, apa lagi menggunakan objek perusahaan Indonesia, sehingga merasa perlu untuk melaksanakan penelitian Pengaruh Kebijakan Deviden Terhadap Kinerja Perusahaan Pertambangan (Studi Empiris Pada Perusahan Manufaktur di Bursa Efek Indonesia Tahun 2016-2018).

Perumusan masalah dalam penelitian ini adalah : bagaimana pengaruh kebijakan dividen, corporate govenance dan kebijakan dividen terhadap kinerja perusahaan. Tujuan penelitian ini : untuk mengetahui pengaruh kebijakan dividen, corporate governance dan kebijakan dividen terhadap kinerja perusahaan. Urgensi penelitian dimana industri pertambangan merupakan industri penting bagi pemerintah pusat sebagai sumber pendanaan membiayai pembangunan, dimana kinerja perusahaan dalam hal ini industri telah menjadi bagian yang sangat penting. Perhatian peran tata kelola perusahaan dalam memoderasi hubungan antara kebijakan dividen dan kinerja harus terus ditingkatkan. Penelitian ini akan memperkaya kebijakan dividen dan perusahaan terhadap tata kelola.

\section{TINJAUAN PUSTAKA}

Persepektif hubungan keagenan merupakan dasar yang digunakan untuk memahami corporate governance. Jensen dan Meclkilng (1976) menyatakan bahwa hubungan keagenan adalah sebuah kontrak antara manajer (agent) dengan investor (principal). Konflik kepentingan antara pemilik dan agen terjadi karena kemungkinan agen tidak selalu berbuat sesuai dengan kepentingan principal sehingga memicu biaya keagenan (ageny cost).

Konsep teori agensi adalah hubungan atau kontrak antara principal dan agen. Principal memperkerjakan agen untuk melakukakn tugas untuk kepentingan principal, termasuk pendelegasian otorisasi pengambilan keputusan dari principal kepada agen (Anthony dan Govindarajan, 2005). Pada perusahaan yang modalnya terdiri atas saham, pemegang saham bertindak sebagai principal, dan $C E O$ (Chief Executif officer) sebagai agen mereka. Pemegang saham memperkerjakan CEO untuk bertindak sesuai dengan kepentingan principal.

Berdasarkan asumsi sifat dasar manusia tersebut sebagai manusia akan bertindak opportunistic, yaitu mengutamakan kepentingan pribadinya (Haris, 2004). Corporate governace yang merupakan konsep yang didasarkan pada teori agensi, diharapkan dapat berfungsi sebagai alat untuk memberi keyakinan kepadad investor bahwa mereka akan menerima return atas dana yang mereka investasikan. Corporate governance sangat berkaitan dengan bagaimana membuat para investor yakin bahwa manajer tidak akan mencuri/menggelapkan atau menginvetasikan kedalam proyek proyek yang tidak menguntungkan berkaitan dengan bagaimana para investor mengendalikan para manajer (Shleifer dan Vishany, 1996).

\section{Kinerja Perusahaan}

Kinerja Perusahaan merupakan suatu gambaran kondisi keuangan perusahaan yang diukur dengan analisis rasio keuangan, serta mengetahui kemampuan keuangan perusahaan yang mencerminkan prestasi kerja dalam periode tertentu. Kaplan dan Norton (1992) membagi pengkuran kinerja perusahaan ke dalam empat perspektif yaitu keuangan, pemasaran, pembelajaran dan pertumbuhan, dan inovasi. Kinerja keuangan bisa di ukur dengan menggunakan accounting performance dan market performance. kinerja akuntansi menggunakan informasi akuntansi, seperti Return on asset (ROA), dan sedangkan kinerja pasar bisa di ukur dengan menggunakan rasio nilai pasar dibandingkan dengan nilai buku (MBV).

Kinerja keuangan perusahaan merupakan salah satu dasar penilaian kondisi suatu perusahaan, untuk itu dibutuhkan suatu peralatan tertentu, berupa alat analisis berupa rasio rasio keuangan. Dari sudut pandang investor, meramalkan masa depan adalah hakikat dari analisis laporan keuangan akan bermanfaat baik untuk membantu untuk mengantisipasi kondisi kondisi dimasa depan maupun yang lebih penting lagi, sebagai titik awal untuk melakukan perencanaan langkah langkah akan meningkatkan kinerja perusahaan dimasa yang akan datang.

Bringham dan houston (2011) menjelaskan bahwa profitabilitas adalah hasil akhir dari sejumlah kebijakan dan keputusan yang dilakukan oleh perusahaan. profitabilitas juga merupakan sekelompok rasio yang menunjukkan kombinasi dari pengaruh likuiditas, manajemen aset dan 
utang pada hasil operasi profitabilitas dapat dinilai menggunakan beberapa rasio antara lain profit margin on sales, Return on Aset (ROA) Return On Equity (ROE) dan Basic Earning Power (BEP). Rasio yang paling tepat digunakan saat ini adalah Return On Asset (ROA), karena rasio ini mampu memberikan tolak ukur untuk menilai kegiatan operasi perusahaan. rasio ini juga melihat seberapa baik manajemen memberdayakan aset yang dimiliki perusahaan dalam menghasilkan keuntungan operasi sehingga dapat memberikan gambaran efisiensi operasi perusahaan secara keseluruhan (mulyono, 2008). Return On Equity (ROE) merupakan rasio pengukuran rasio yang menunjukkan seberapa besar pendapatan yang diterima bagi pemegang saham terhadap investasi yang ditanamkan (Syamsudin,2009:65) jadi rasio ini merupakan kemampuan perusahaan dalam menggunakan modal yang dimiliki untuk memperoleh laba. sedangkan Secara sederahanaTobin 'sq adalah pengukuran kinerja dengan membandingkan dua penilaian dari aset yang sama. Tobin'sq merupakan rasio dari nilai pasar asset perusahaan yang diukur oleh nilai pasar dari jumlah saham yang beredar dan hutang (enterprise value) terhadap replacement cost dari aktiva perusahaan (Fiakas,2005). Apabila perusahaan memiliki nilai lebih besar dari nilai dasar sebelumnya, maka akan memiliki biaya untuk meningkatkan kembali, dan laba kemungkinan akan didapatkan. Berdasarkan pemikiran Tobin, bahwa insentif untuk membuat modal investasi baru adalah tinggi ketika surat berharga (saham) memberikan keuntungan di masa depan dapat dijual dengan harga yang lebih tinggi dari biaya investasinya (Fiakas, 2005).Tobin'sq merupakan indikator yang digunakan sebagai pengukuran variabel yang harus diuji terlebih dahulu untuk mengetahui ketepatannya. Tobin'sq sebagai salah satu indikator pengukuran variabel kinerja perusahaan dari perpektif investasi telah diuji diberbagai situasi manajemen puncak (Wolfe and Sauaia,2003). Tobin'Sq digunakan oleh Klapper dan Love (2002) yang menemukan adanya hubungan positif antara corporate governance terhadap Kinerja Perusahaan. Penelitian ini menggunakan data dari laporan Credit Lyonnals Securities Asia (CLSA) yang berupa pemeringkatan penerapan corporate governance untuk 495 perusahaan di 25 negara, dalam penelitian ini kinerja perusahaan diukur dengan menggunakan Tobins'Q sebagai ukuran penilaianpasar dan Return On Assets (ROA) sebagai ukuran kinerja operasional perusahaan.

\section{Kebijakan Dividen}

Menurut Bringham dan Houston (2011) kebijakan dividen adalah "kebijakan mengenai berapa banyak laba saat ini yang akan dibayarkan sebagai dividen sebagai ganti dari dipertahankan untuk diinvestasikan kembali kedalam perusahaan". Jadi kebijakan dividen merupakan salah satu aspek penting dibahas dimanajemen keuangan, selain dari kebijakan investasi, pendanaan dan kebijakan modal kerja. Kebijakan dividen menjadi strategis karena mempengaruhi kebijakan lainnya, misalnya perusahaan memutuskan membayarkan semua laba yang diperoleh pada waktu tertentu sebagai dividen, maka perusahaan tidak punya dana laba ditahan sebagai pendanaan dari dalam jika ada peluang investasi atau pengembangan bisnis perusahaan terpaksa menggunakan modal asing sebagai sumber dana. Oleh karena itu, kebijakan dividen diukur dengan rasio pembayaran dividen (dividen payout ratio) menurut Sartono (2009:491) menyatakan bahwa rasio pembayaran dividen (DPR) adalah persentase laba yang dibayarkan dalam bentuk dividen, atau rasio antara laba yang dibayarkan dalam bentuk dividen dengan total laba yang tersedia bagi pemegang saham.

Bringham dan Houston (2011) mendefenisikan dividen adalah keuntungan perusahaan yang berbentuk perseroan terbatas yang diberikan kepada para pemegang saham. selanjutnya, kebijakan dividen adalah besarnya dividen yang diberikan kepada pemegang saham dari laba yang dihasilkan pada tahun yang bersangkutan. Fenomena pembayaran dividen atau kebijakan dividen dijelaskan oleh beberapa teori.

\section{Corporate Governance}

Corporate governance merupakan pengendalian untuk mengatur dan mengelola perusahaan dengan maksud untuk meningkatkan kemakmuran dan akuntabilitas perusahaan, yang tujuan akhirnya untuk mewujudkan shareholder value (Monk dan Minow, 2008).dan juga beberapa defenisi tentang corporate governance yaitu : The whole set of legal, cultural and institutional arrangement that determines what publicly traded corporations can do, who controls them, how that control is exercised, and how the the risk and returns from the activities they undertake are allocated (Blair, 1995,p.3). Menurut World Bank (1999) mekanisme pengendalian corporate governance dibagi menjadi dua, yaitu mekanisme eksternal dan internal. Mekanisme eksternal antara lain terdiri dari: pasar modal, pemberi dana, konsumen, dan regulator. Sedangkan mekanisme internal terdiri daristruktur kepemilikan saham, independensi anggota dewan komisaris, dan ukuran dewan komisaris. 
Dimaksudkan dengan corporategovernance sebenarnya berkaitan dengan masalah siapa yang mengendalikan perusahaan, dan mengapa itu terjadi (Riyanto ,2003). Dari perspektif hukum, pemilik adalah pihak yang mempunyai kendali atau perusahaan. tetapi kenyataanya yang sering terjadi, manajer yang memilki kendali penuh atas perusahaan, sementara pemilik tidak dapat mempengaruhi jalanya perusahaan. hal ini menjadi masalah karena dalam banyak kasus manajer kurang memberikan kontribusi terhadap pertumbuhan (kinerja) perusahaan. discretion atas penggunaan resource perusahaan yang telah didelegasikan oleh pemilik kepada manajer tidak sepenuhnya digunakan untuk keperluan pemilik. Masalahnya ini muncul karena adanya pemisahan antara kepemilikan dan pengelola perusahaan. ketika kepemilikan terdistribusi secara luas atau kepemilikan oleh masyarakat melalui pasar modal, menyebabkan pemilik semakin tidak dapat melakukan kontrol yang efektif terhadap manajer yang mengelolah perusahaan.

Target kontrol adalah discreation dan decision manajemen. Maksudnya maksudnya kontrol terhadap perusahaan diarahkan pada pengawasan perilaku manajer. Sehingga tindakan yang dilakukan manajer dapat dinilai apakah bermanfaat bagi perusahaan ataukah hanya bagi para manajer sendiri. Kontrol lebih diarahkan pada upaya pengelolaan perusahaan yang terbuka (transparansi), dapat dipertanggungjawabkan (accountable), dan proses monitoring ( Riyanto, 2003).

\section{Pengaruh Kebijakan dividen terhadap Kinerja Perusahaan}

Kebijakan dividen adalah suatu keputusan untuk menentukan besarnya bagian laba yang dibagikan kepada para pemegang saham. kebijakan dividen ini sangat penting bagi perusahaan, karena pembayaran dividen mungkin mempengaruhi kinerja perusahaan yang merupakan sumber dana internal yang terbesar dan terpenting bagi pertumbuhan suatu perusahaan. sedangkan bagi seorang investor dividen adalah merupakan komponen return disamping capital gain (Bringham dan Houston,2006).

Teory keagenan menjelaskan bahwa pembayaran dividen dapat mengurangi masalah yang berhubungan dengan information Asymmetry. Asimetri informasi dapat dijelaskan dengan teori keagenan (agency theory), yang menjelaskan bahwa hubungan agensi muncul ketika satu orang atau lebih (principal) mempekerjakan orang lain (agent) untuk memberikan suatu jasa dan kemudian mendelegasikan wewenang pengambilan keputusan kepada agen tersebut (Jensen dan Meckling, 1976).

Beberapa studi empiris dengan hasil yang menunjukkan dukungannya terhadap pandangan bird in the hand theory adalah sebagai berikut : Long (1978) secara cermat menguji kasus Citizen Utilities, suatu perusahaan yang mempunyai dua kelompok saham yaitu satu kelompok membayar dividen tunai dan kelompok lainnya membayar dividen saham. ia menemukan bahwa bukti bahwa para pemegang saham lebih menyukai dividen tunai. Hasil penelitian Bhattacharya (1979) membenarkan bird in the hand theory dari lintner (1962) dan gordon (1963) yang menjelaskan bahwa investor lebih menyukai dividen yang tinggi karena dividen yang diterima risikonya lebih kecil atau mengurangi ketidakpastian dibandingkan dengan keuntungan yang tidak dibagikan dalam bentuk laba ditahan (capital gain).

Amidu (2006)melakukan penelitian untuk menguji apakah kebijakan dividen berpengaruh terhadap kinerja keuangan perusahaan. Penelitian dilakukan pada perusahaan-perusahaan yang terdaftar di Ghana Stock Exchange (GSE), dengan menggunakan data selama delapan tahun yaitu mulai tahun 1997 sampai tahun 2004. Hasil penelitian Amidu (2007) mendukung pernyataan bahwa kebijakan dividen adalah relevan terhadap kinerja perusahaan, yang diukur dengan Tobin's $q$ yaitu rasio nilai pasar dari aset terhadapnilai buku dari aset perusahaan, Return on Asset, dan Return on Equity.

Marselino Wau dan Zaitul (2017) melakukan penelitian bahwa apakah kebijakan dividen berpengaruh terhadap kinerja perusahaan. penelitian ini dilakukan pada Bursa Efek Indonesia (BEI) dengan menggunakan data selama 3 tahun yaitu mulai tahun 2012-2014, Hasil penelitian Marselino Wau dan Zaitul (2017) mendukung pernyataan bahwa kebijakan dividen adalah relevan terhadap kinerja perusahaan, yang diukur dengan Return on Asset .

\section{Pengaruh Corporate governance terhadap kinerja perusahaan}

Berdasarkan studi empiris yang yang melakukan penelitian antara lain Herman darwis (2007) pengaruh corporate governance terhadap kinerja perusahaan. hasil penelitian ini bahwa corporate governance yang diukur dengan Komisaris independen berpengaruh positif terhadap kinerja perusahaan. dan juga didukung marselino wau dan Zaitul (2017) dalam penelitian tentang pengaruh corporate governance terhadap kinerja perusahaan berpengaruh positif terhadap kinerja perusahaan. sedangkan penelitian yang dilakukan Desi Aprina (2011) Pengaruh Kepemilikan Manajerial, Kepemilikan Institusional dan Ukuran Perusahaan terhadap Kinerja Perusahaan yang 
Diukur Menggunakan Economic Value Added dengan hasil penelitiaanya bahwa kepemilikan manajerial tidak berpengaruh terhadap kinerja perusahaan. dan Penelitian yang dilakukan oleh Arifulsyah (2016) Pengaruh Proporsi Kepemilikan Publik Terhadap Kinerja Keuangan Perusahaan, Dengan CSR Disclosure Sebagai Variabel Moderating dengan hasil penelitiannya bahwa kepemilikan publik tidak berpengaruh terhadap kinerja perusahaan

\section{Pengaruh corporate governance terhadap hubungan antara kebijakan dividen terhadap Kinerja perusahaan}

Berdasarkan penelitian penelitian sebelumnya tentang kebijakan dividen dan corporate governance terhadap kinerja perusahaan, terhadap pandangan bird in the hand theory adalah sebagai berikut : Long (1978) menguji kasus Citizen Utilities, dan didukung Hasil penelitian Bhattacharya (1979) membenarkan bird in the hand theory dari lintner (1962) dan gordon (1963) yang menjelaskan bahwa investor lebih menyukai dividen yang tinggi karena dividen yang diterima risikonya lebih kecil atau mengurangi ketidakpastian dibandingkan dengan keuntungan yang tidak dibagikan dalam bentuk laba ditahan (capital gain). Dan Amidu (2007), marselino waudan Zaitul (2017), dan herman darwis (2007) pada hasil penelitiannya bahwa corporate governance diukur dengan komisaris independen berpengaruh terhadap kinerja perusahaan. sedangkan penelitian yang dilakukan Desi Aprina (2011) Pengaruh Kepemilikan Manajerial, Kepemilikan Institusional dan Ukuran Perusahaan terhadap Kinerja Perusahaan yang Diukur Menggunakan Economic Value Added dengan hasil penelitiaanya bahwa kepemilikan manajerial tidak berpengaruh terhadap kinerja perusahaan. dan Penelitian yang dilakukan oleh Hamdani Arifulsyah (2016) Pengaruh Proporsi Kepemilikan Publik Terhadap Kinerja Keuangan Perusahaan, Dengan CSR Disclosure Sebagai Variabel Moderating. Dari perspektif dari teori keagenan (agency theory) dimana teori ini memprediksi bahwa terjadinya konflik manajemen dan pemilik perusahaan (pricipal-agent conflic). Dalam konteks kebijakan dividen, pemilik akan memaksa manajemen untuk membayarkan dividen sehingga free cashflow menjadi sedikit untuk bisa digunakan oleh manajemen dalam investasi pada proyek yang tidak menguntungkan (Easterbrook, 1984). Secara teori dapat di simpulkan bahwa corporate governance akan meminimalisasi prilaku opportunistik dari manajemen. Untuk itu, corporate governance di perkirakan akan memperkuat pengaruh kebijakan dividen terhadap kinerja perusahaan.

\section{Kerangka konseptual}

Variabel bebas : Kebijakan deviden, variable terikat kinerja perusaaan dengan variable permoderasi Corporate Governance Komisaris Independent dan Kepemilikan manajerial.

\section{METODE PENELITIAN}

\section{Jenis penelitian}

Jenis penelitian deskriptif verikatif yan bersifat kausalitas, untuk mengetahui dan menjelaskan karaktersitik variabel yang diteliti.

\section{Objek, Populasi dan Sampel Penelitian}

Objek penelitian ini adalah Perusahaan Batubara, Minyak dan Gas Bumi, Logam dan Mineral dan Batu batuan dan subsektor lainnya yang terdaftar di bursa efek indonesia (BEI) pada tahun 2016-2018.

\section{Teknik Pengumpulan Data}

Data dalam penelitian ini bersumber dari data sekunder, dimana data tersebut sudah ada yang berasal dari laporan tahunan/keuangan perusahaan pertambangan yang sudah dipublikasikan di bursa efek indonesia.

\footnotetext{
Analisis

Analisis dilakukan mulai dari Analisis deskriptif untuk menggambarkan karakteristik masing masing variabel penelitian, selanjutnya Uji Autokorelasi untuk mengetahui apakah ada korelasi antara anggota serangkaian data observasi yang diuraikan menurut waktu (time series) atau ruang (cross section). Uji Durbin Watson hanya digunakan untuk autokorelasi tingkat satu dan mensyaratkan adanya konstanta dalam model regresi dan tidak ada variabel independen, serta Uji asumsi klasik dengan uji Multikolinearitas dan uji heteroskedastisitas.
} 


\section{Uji Statistik}

a. Pengujian Koefisien Regresi Secara Individual (Uji t)

Pengujian hipotesis dapat didasarkan dengan menggunakan dua hal yaitu tingkat signifikansi atau probabilitas $(\alpha)$ dan tingkat kepercayaan convidence interval. Kisaran tingkat signifikansi dalam penelitian ini 0,05 .

Dalam melakukan uji hipotesis terdapat dua hipotesis :

1. $\mathrm{H}_{0}$ (Hipotesis nol)

Hipotesis Nol (Null hipotesis) $H_{0}$ : pernyataan dengan nilai parameter suatu populasi yang diasumsikan akan benar jika kita melakukan uji suatu hipotesis. Artinya $\leq$ (lebih kecil atau sama dengan) $\geq$ (lebih besar atau sama dengan) atau = (sama dengan)

2. $\mathrm{H}_{1}$ (Hipotesis alternatif)

Pernyataan tentang nilai parametrik suatu populasi yang harus benar jika $\mathrm{H}_{0}$ ternyata salah. Artinya < (lebih kecil) > (lebih besar) atau = (sama dengan). Untuk mengetahui kebenaran hipotesis digunakan kriteria sebagai berikut :

- $\quad \mathrm{H}_{0}$ diterima apabila $-\mathrm{t}(\alpha / 2, \mathrm{n}-\mathrm{k}) \leq \mathrm{t}_{\text {hitung }}-\mathrm{t}(\alpha / 2, \mathrm{n}-\mathrm{k})$ artinya tidak ada pengaruh antara variabel bebas terhadap variabel terikat.

- $\quad \mathrm{H}_{0}$ ditolak apabila $\mathrm{t}_{\text {hitung }}>-\mathrm{t}(\alpha / 2, \mathrm{n}-\mathrm{k}) \leq \mathrm{t}_{\text {hitung }}-\mathrm{t}(\alpha / 2, \mathrm{n}-\mathrm{k})$ artinya ada pengaruh antara variabel bebas terhadap variabel terikat.

Dalam penelitian ini menggunakan tarat signifikan $(\alpha)$ sebesar 5\%, atau tingkat keyakinan 95\% sedangkan $\mathrm{df}=\mathrm{n}-\mathrm{k}$, dengan $\mathrm{n}$ adalah ukuran sampel pada regresi ini dan $\mathrm{k}$ adalah banyaknya variabel regresi. Untuk menghitung nilai statistiknya secara parsial (t hitung) dapat dirumuskan sebagai berikut :

to $=\mathrm{b} 1-\beta 1$

Sb 1

b1 = koefisien regresi parsial yang ke $-\mathrm{i}(\mathrm{i}=1,2)$ dari regresi sampel

$\beta 1=$ koefisien parsial yang ke $\mathrm{i}(\mathrm{i}=1,2)$ dari regresi populasi

$\mathrm{Sb}_{1}=$ kesalahan standar (standat error) koefisien regresi sampel

$1=\operatorname{sektor}(i=1,2$ dan 3$)$

b. Pengujian Koefisien Regresi secara serentak (Uji F)

Uji f adalah metode pengujian yang dilakukan untuk mengetahui pengaruh variabel bebas secara bersama sama terhadap variabel terikat (Ghojali, 2006) langkah langkah untuk melakukan uji f adalah sebagai berikut :

1. Merumuskan hipotesis

2. Menentukan taraf signifikan $=\alpha=5 \%$

Derajat bebas (df) dalam distribusi f ada dua yaitu :

- Df numerator $=\mathrm{dfn}=\mathrm{df}_{1}=\mathrm{k}-1$

- $\quad$ Df pada denumerator $=\mathrm{dfd}=\mathrm{df}_{2}=\mathrm{n}-\mathrm{k}$

3. Menentukan daerah keputusan dimana hipotes nol diterima atau tidak

a. $\mathrm{H}_{0}$ diterima apabila $\mathrm{F}_{\text {hitung }} \leq \mathrm{F}$ tabel artinya semua variabel bebas secara bersama sama bukan merupakan variabel penjelas yang signifikan terhadap variabel terikat

b. $\mathrm{H}_{0}$ ditolak apabila apabila $\mathrm{F}_{\text {hitung }}>\mathrm{F}_{\text {tabel }}$ artinya semua variabel bebas secara bersama sama bukan merupakan variabel penjelas yang signifikan terhadap variabel terikat

Untuk menghitung nilai stattistik uji satu sisi secara simultan (F hitung) menurut wirawan (2001) dirumuskan sebagai beriku :

$F=\frac{R^{2} / k-1}{\left(1-R^{2} /(n-k)\right.}$

Keterangan:

R2 = Koefisien determinasi

$\mathrm{K}$ = banyakmnya variabel dalam model regresi

$\mathrm{N}=$ Ukuran sampel

\section{HASIL PENELITIAN}

Dengan hadirnya perusahaan pertambangan memiliki manfaat yang dirasakan oleh seluruh masyarakat indonesia, karena sumber daya tambang merupakan bangsa indonesia yang harus dikelola dan dipergunakan sebesar sebesarnya untuk kepentingan penduduknya. Perusahaan Pertambangan dikelola oleh pemerintah maupun swasta yang dimanfaatkan untuk berbagai keperluan, baik skala besar seperti PLN, Indutri,kendaraan bermotor, selain dimanfaatkan untuk 
konsumsi dalam Negeri, produksi minyak bumi dan gas alam indonesia juga diekspor ke berbagai negara lain.

Adapun beberapa manfaat sumber daya tambang di Indonesia adalah sebagai berikut

1. Untuk Menambah pendapatan Negara.

2. Untuk memperluas lapangan kerja

3. Untuk memajukan bidang trasnportasi dan komunikasi

4. Untuk memajukan industri dalam negeri

5. Sebagai pemasok kebutuhan SDA barang tambang dan galian dalam Negeri

6. Minyak Bumi dan gas alam sebagai bahan bakar atau sumber energi.

7. Pasir atau Batu sebagai bahan bangunan

8. Emas, Intan dan perak sebagai perhiasan

9. Sebagai Bahan Industri dalam negeri

Penelitian ini dilakukan dengan tujuan untuk menguji pengaruh kebijakan dividen terhadap kinerja perusahaan corporate governance sebagai variabel Moderasi pada perusahaan sektor utama di Bursa Efek Indonesia (BEI\} periode 2012 s/d 2017. Data sekunder diperoleh dari Capital Market of Directory, Annual Report dan Website perusahaan, (www.idx.co.id . Dalam penentuan sampel yang dapat mewakili populasi maka proses pemilihan sampel dilakukan seperti yang tersaji dibawah ini : Perusahaan Sektor Utama terdaftar BEI pada tahun 2012-2017 sebanyak 106 perusahaan, Perusahaan Sektor Utama yang tidak membagi dividen konsisten dan Annual Report yang tidak lengkap sebanyak 81 perusahaan dan Jumlah Perusahaan Sektor Utama yang menjadi Sampel sebanyak 25 perusahaan. Sumber ; www.idx.co.id

\section{Deskriptif Statistik}

Deskriptif statistik bertujuan untuk menggambarkan secara umum semua data atau variabel penelitian yang digunakan dalam penelitian ini dimana penilaian deskriptif statistik dapat dilihat dari nilai penyebaran data minimum, maksimum, rata rata (mean \} dan nilai standar deviasi atau simpang baku, dari penyajian pengujian ini diharapkan peneliti dan pembaca dapat mengetahui informasi yang ringkas dari paparan data yang luas untuk semua variabel variabel penelitian. Hasil observasi data penelitian sejumlah 25 perusahaan sektor utama sepanjang tahun 2012 sampai dengan 2017, diketahui gambaran data untuk variabel ROA bahwa perusahaan sektor utama memiliki penyebaran data terendah (Min \} sebesar -49,6 perlembar jumlah saham yang beredar dengan penyebaran data tertinggi (Max \}sebesar 42,6 perlembar jumlah saham yang beredar, dengan nilai rata rata (Mean\} sebesar 6,54 dan standar deviasi masing Masing sebesar 8,041255536. Perlembar jumlah saham yang beredar. Hal ini menunjukkan secara umum perusahaan pertambangan sepanjang periode pengamatan ini masih memiliki penyebaran ROA yang tidak merata.

Untuk variabel Tobinsq diketahui nilai penyebaran data terendah (Min) sebesar 3,35 perlembar jumlah saham yang beredar dengan penyebaran data tertinggi (Max \}sebesar 93,4 perlembar jumlah saham yang beredar, dengan nilai rata rata (Mean \} sebesar 6,73 dan standar deviasi masing Masing sebesar 19,43784945. Perlembar jumlah saham yang beredar. Hal ini menunjukkan secara umum perusahaan pertambangan sepanjang periode pengamatan ini masih memiliki penyebaran Tobinsq yang merata.

Untuk variabel Dpr diketahui nilai penyebaran data terendah (Min $)$ sebesar 0,00 perlembar jumlah saham yang beredar dengan penyebaran data tertinggi (Max \} sebesar 80,00 perlembar jumlah saham yang beredar, dengan nilai rata rata (Mean sebesar 17,9 dan standar deviasi masing Masing sebesar 17,65701069. Perlembar jumlah saham yang beredar. Hal ini menunjukkan secara umum perusahaan pertambangan sepanjang periode pengamatan ini masih memiliki penyebaran Dpr yang baik.

Untuk variabel Dki diketahui nilai penyebaran data terendah (Min) sebesar 25,0 perlembar jumlah saham yang beredar dengan penyebaran data tertinggi (Max \} sebesar 60,00 perlembar jumlah saham yang beredar, dengan nilai rata rata (Mean\} sebesar 40,3 dan standar deviasi masing Masing sebesar 8,268560858. Perlembar jumlah saham yang beredar. Hal ini menunjukkan secara umum perusahaan pertambangan sepanjang periode pengamatan ini masih memiliki penyebaran Dpr yang baik.

Untuk variabel Kp diketahui nilai penyebaran data terendah (Min) sebesar 2,80 perlembar jumlah saham yang beredar dengan penyebaran data tertinggi (Max \}sebesar 79,7 perlembar jumlah saham yang beredar, dengan nilai rata rata (Mean\} sebesar 28,8 dan standar deviasi masing Masing sebesar 14,330703. Perlembar jumlah saham yang beredar. Hal ini menunjukkan secara umum perusahaan pertambangan sepanjang periode pengamatan ini masih memiliki peningkatan Kepemilikan Publik yang baik. 
Untuk variabel $\mathbf{K m}$ diketahui nilai penyebaran data terendah (Min) sebesar 0,00 perlembar jumlah saham yang beredar dengan penyebaran data tertinggi (Max \}sebesar 32,5 perlembar jumlah saham yang beredar, dengan nilai rata rata (Mean \} sebesar 13,3 dan standar deviasi masing Masing sebesar 12,47053968. Perlembar jumlah saham yang beredar. Hal ini menunjukkan secara umum perusahaan pertambangan sepanjang periode pengamatan ini masih memiliki peningkatan Kepemilikan Manajerial yang baik.

Untuk variabel $\mathbf{L v}$ diketahui nilai penyebaran data terendah (Min \} sebesar perlembar jumlah saham yang beredar dengan penyebaran data tertinggi (Max $\}$ sebesar 98,0 perlembar jumlah saham yang beredar, dengan nilai rata rata (Mean \} sebesar 43,9 dan standar deviasi masing Masing sebesar 23,9450463. Perlembar jumlah saham yang beredar. Hal ini menunjukkan secara umum perusahaan pertambangan sepanjang periode pengamatan ini masih memiliki peningkatan Leverage yang tinggi.

Untuk variabel Gp diketahui nilai penyebaran data terendah (Min \} sebesar $\quad-36,6$ perlembar jumlah saham yang beredar dengan penyebaran data tertinggi (Max \}sebesar 99,5 perlembar jumlah saham yang beredar, dengan nilai rata rata (Mean\} sebesar 10,1 dan standar deviasi masing Masing sebesar 15,88890336. Perlembar jumlah saham yang beredar. Hal ini menunjukkan secara umum perusahaan pertambangan sepanjang periode pengamatan ini masih memiliki peningkatan growt perusahaan yang tinggi.

Untuk variabel Ump diketahui nilai penyebaran data terendah (Min \} sebesar perlembar jumlah saham yang beredar dengan penyebaran data tertinggi (Max $\}$ sebesar 55,0 perlembar jumlah saham yang beredar, dengan nilai rata rata (Mean \} sebesar 23,6 dan standar deviasi masing Masing sebesar 13,97454193. Perlembar jumlah saham yang beredar. Hal ini menunjukkan secara umum perusahaan pertambangan sepanjang periode pengamatan ini masih memiliki peningkatan growt perusahaan yang tinggi.

Untuk variabel Uk diketahui nilai penyebaran data terendah (Min) sebesar 1,07 perlembar jumlah saham yang beredar dengan penyebaran data tertinggi (Max \}sebesar 36,4 perlembar jumlah saham yang beredar, dengan nilai rata rata (Mean \} sebesar 8,32 dan standar deviasi masing Masing sebesar 8,386006734. Yang merupakan simpang baku atau rata rata, data ini juga memperlihatkan bahwa pasar modal yang secara rata rata dapat dikatakan baik karena memiliki nilai diatas 0,5 dengan tingkat penyebaran data terttinggi 67,2 bahwa pasar menunjukkan bahwa pasar memiliki perhatian yang baik terhadap perusahaan pertambangan sepanjang tahun pengamatan 2012 s/d 2017 dan Hal ini menunjukkan secara umum perusahaan pertambangan sepanjang periode pengamatan ini masih memiliki peningkatan growt perusahaan yang tinggi

\section{Hasil Uji Outlier}

Data outier merupakan data pencilan, dimana data obesrvasi yang muncul dengan nilai nilai ekstrim, baik secara univariat ataupun multivariate.

\section{Uji asumsi klasik}

\section{Uji normalitas}

Uji normalitas dlilakukan untuk menguji apakah dalalm model Moderating Regression Analysis (MRA) dengan menggunakan kriteria nilai kritis sebesar $\pm 2,59$ pada tingkat signifikan 0,01 , dan setelah telah dilakukan uji outlier dan membuang nilai pengganggu yaitu data yang rentangnya jauh dari rata masing masing variabel

Dengan mencari nilai zscore setiap variabel dan membuang data yang nilai zscore diatas + 2,59 dan - 2.50 (Manning dan Munro 2004), dengan demikian, apabila nilai kritis dari hasil penelitian ini lebih besar dari kriteria nilai kritis tersebut, maka dapat didiga bahwa distribusi data adalah tidak normal. Uji normalitas dapat dilakukan dengan berdasarkan pada koefisien kemiringan (kurtosis \} dan koefisien kemiringan (skewness \}. Tabel diatas menunjukkan bahwa variabel terikat lebih kecil dari $\pm 2,59$ yaitu untuk variabel return on asset (ROA $\}$ dengan nilai skewness sebesar 0,0199 dan juga variabel Tobin'sq dengan nilai skewness sebesar 0,0199, yang berarti variabel y nilainya jauh lebih kecil dari nilai batas $\pm 2,59$. Dengan demikian, dapat ditarik kesimpulan bahwa hasil penilaian normalitas terhadap data penelitian yang digunakan dalam penelitian ini adalah normal secara model skewnes yang berarti sangat layak untuk digunakan dalam estimasi selanjutnya.

\section{Uji Multikolinearitas}

\section{Model ROA (Returnon Asset)}

Uji multikolinearitas pada penelitian ini adalah menggunakan metode pengujian VIF (Variance Inflation Factor). Apabila nilai VIF lebih besar dari 10, maka variabel tersebut mempunyai persoalan multikolinearitas dengan variabel bebas lainya. Begitu sebaliknya apabila 
nilai VIF kecil dari 10, maka variabel tersebut tidak mempunyai persoalan multikolinearitas dengan variabel bebas lainnya.

Berdasarkan output pada coefficient terlihat bahwa nilai TOL (Tolerance) variabel Dpr, Dki, Kp,Km,Lv,Gp, Ump, Uklebih kecil dari Nilai TOL 0,10. sedangkan VIF (Variance Inflation Factor) 10 lebih kecil dari Dpr, Dki, Kp,Km,Lv,Gp, Ump, Uk, maka dapat disimpulkan bahwa variabel tidak terjadi multikolinearitas.

\section{TOBIN SQ}

Uji multikolinearitas pada penelitian ini adalah menggunakan metode pengujian VIF (Variance Inflation Factor). Apabila nilai VIF lebih besar dari 10, maka variabel tersebut mempunyai persoalan multikolinearitas dengan variabel bebas lainya. Begitu sebaliknya apabila nilai VIF kecil dari 10, maka variabel tersebut tidak mempunyai persoalan multikolinearitas dengan variabel bebas lainnya.

Berdasarkan output pada coefficient terlihat bahwa nilai TOL (Tolerance) variabel Dpr, Dki, Kp,Km,Lv,Gp, Ump, Uk lebih kecil dari Nilai TOL 0,10. sedangkan VIF (Variance Inflation Factor) 10 lebih kecil dari Dpr, Dki, Kp,Km,Lv,Gp, Ump, Uk, maka dapat disimpulkan bahwa variabel tidak terjadi multikolinearitas.

\section{Uji Autokorelasi}

\section{a. Model ROA (Return On Asset)}

Uji Autokorelasi dalam penelitian ini dilakukan dengan uji Durbin-Watson. Dari pengujian autokorelasi di atas dapat diketahui bahwa nilai DW hasil olahan di atas adalah 1.543986. Oleh karena itu nilai DW berada di daerah tanpa keputusan, sehingga berada pada daerah tersebut tidak ada autokorelasi. Dengan demikian model dalam penelitian ini tidak mengandung masalah autokorelasi.

\section{b. Model Tobin sq}

Uji Uji Autokorelasi dalam penelitian ini dilakukan dengan uji Durbin-Watson. Dari pengujian autokorelasi di atas dapat diketahui bahwa nilai DW hasil olahan di atas. Oleh karena itu nilai DW berada di daerah tanpa keputusan, sehingga berada pada daerah tersebut tidak ada autokorelasi. Dengan demikian model dalam penelitian ini tidak mengandung masalah autokorelasi.

\section{Uji heteroskedasitisitas}

Berdasarkan uji heteroskledastisitas dengan metode white test untuk

menguji apakah dalam model regresi terjadi ketidaksamaan variance dari residual satu pengamatan ke pengamatan lain, penelitian ini dengan kriteria sebagai berikut

- Tidak terjadi heteroskedastisitas, jika nilai $\mathrm{t}$ hitung lebh kecil dari $\mathrm{t}$ tabel dan nilai signifikan lebih besar 0,05

- Terjadi heteroskedastisitas, jika nilai t hitung lebh besar dari t tabel dan nilai signifikan lebih kecil 0,05

Berdasarkan pengujian heteroskedastisitas dengan white tesbahwa bahwa ketiga model satu dan tiga pada alpha 0,05 artinya dapat disimpulkan tidak terjadi heteroskedastisitas.

\section{Uji hipotesis}

Hiptesis merupakan asumsi atau dugaan mengenai suatu hal yang dibuat untuk menjelaskan hal tersebut dan dituntut untuk melakukan pengecekannya Berdasarkan hipotesis yang dikembangkan dalam penelitian ini yaituKD,DKI,KP,KM,LV,GP,UMP dan UK yang berpengaruh pada ROA dan TOBINSQ yang menggunakan moderating regresi analisis sebagai berikut :

\section{a. Uji F}

Uji $F$ digunakan untuk mengetahui variabel independen dan variabel moderasi (KD,DKI,KP dan KM) secara bersama sama koefisien berpengaruh secara signifikan terhadap variabel terikat atau digunakan untuk mengetahu apakah model ini dapat memprediksi variabel terikat atau tidak, dari hasil estimasi pada tabel 4.1.5.1, didapatkan nilai Model ROA 1 probabilitas $\mathrm{F}$ $(0,04823)$ yang kecil dari $\alpha=0,05$ dan Model Tobin Sq didapatkan nilai probabilitas $\mathrm{F}$ (0,000805) yang kecil dari $\alpha=0,05$. Dengan demikian bahwa variabel independen berpengaruh signifikan terhadap nilai kinerja perusahaan.

b. Koefisien Determinan $\left(\mathbf{R}^{2}\right)$ $\mathrm{R}^{2}$ digunakan untuk mengukur seberapa besar proporsi variasi dari variabel independen secara 
bersama sama dalam mempengaruhi variabel dependen. Dari hasil pengolahan data ditemukan Model $\mathrm{ROA}_{1}$ nilai $\mathrm{R}^{2}$ sebesar 0,07386 ini bahwa variabel independen $(\mathrm{KD})$ dan variabel control (LV,GP,UMP dan UK mempengaruhi kinerja perusahaan sebesar 73,86\% sedangkan sisanya 26,14 dipengaruhi oleh faktor lain.

c. T.Statistik

Dari Tabel diatas dihasilkan nilai koefisien regresi untuk variabel Kebijakan Dividen sebesar 0,0135619 bertanda tidak signifikan dengan nilai p-value 0,5196>0,05 yang berarti bahwa kebijakan dividen tidak berpengaruh terhadap kinerja perusahaan, dan juga Model Tobinsq kebijakan dividen sebesar 0,139155 bertanda tidak signifikan dengan nilai p-value 0,1194>0,05 yang berarti kebijakan dividen tidak berpengaruh terhadap kinerja perusahaan. Dengan demikian dapat disimpulkan hipotesis pertama ditolak.

Pengaruh Corporate Governance terhadap Kinerja perusahaan :

a. $\mathbf{U j i} \mathbf{F}$

Uji F digunakan untuk mengetahui variabel independen dan variabel moderasi (KD,DKI,KP dan KM) secara bersama sama koefisien berpengaruh secara signifikan terhadap variabel terikat atau digunakan untuk mengetahu apakah model ini dapat memprediksi variabel terikat atau tidak, dari hasil estimasi pada tabel 4.1.5.2, didapatkan nilai Model ROA $_{2}$ probabilitas F $(0,023254$ lebih besar dari $\alpha=0,05$ dan Model Tobin $\mathrm{Sq}_{2}$ didapatkan nilai probabilitas $\mathrm{F}(0,001609)$ yang kecil dari $\alpha=0,05$. Dengan demikian bahwa variabel independen model tobinsq ${ }_{2}$ berpengaruh signifikan terhadap nilai kinerja perusahaan.

b. Koefisien Determinan $\left(\mathbf{R}^{2}\right)$

$\mathrm{R}^{2}$ digunakan untuk mengukur seberapa besar proporsi variasi dari variabel independen dan Moderasi secara bersama sama dalam mempengaruhi variabel dependen. Dari hasil pengolahan data ditemukan Model $\mathrm{ROA}_{2}$ nilai $\mathrm{R}^{2}$ sebesar 0,115951 ini bahwa variabel independen dan moderasi (CP) dan variabel control (LV,GP,UMP dan UK mempengaruhi kinerja perusahaan sebesar $11,59 \%$ sedangkan sisanya 88,41 dipengaruhi oleh faktor lain. Dan Model Tobinsq 2 nilai $\mathrm{R}^{2}$ sebesar 0,158919 ini bahwa variabel independen dan moderasi (CP) dan variabel control mempengaruhi kinerja perusahaan $15,89 \%$ sedangkan sisanya 84,11 dipengaruhi oleh faktor lainnya.

c. T.Statistik

Dari Tabel diatas dihasilkan nilai koefisien regresi untuk variabel corporate governance pada $\mathrm{H}_{2 \mathrm{a}}$ kepemilikan manajerial sebesar 0,0730415 bertanda signifikan dengan nilai $\mathrm{p}$-value $0,0409<0,05$ yang berarti bahwa corporate governance berpengaruh terhadap kinerja perusahaan, dan juga Model Tobinsq 2 sebesar 0,225766 bertanda signifikan dengan nilai pvalue 0,0457<0,05 yang berarti corporate governance berpengaruh terhadap kinerja perusahaan. Dengan demikian dapat disimpulkan hipotesis keduaditerima.

\section{Pengaruh Corporate Governance terhadap hubungan antara Kebijakan Dividen dan Kinerja perusahaan.}

\section{Uji F}

Uji F digunakan untuk mengetahui variabel independen dan variabel moderasi (KD,DKI,KP dan KM) secara bersama sama koefisien berpengaruh secara signifikan terhadap variabel terikat atau digunakan untuk mengetahu apakah model ini dapat memprediksi variabel terikat atau tidak, dari hasil estimasi pada tabel 4.1.5.3, didapatkan nilai Model $\mathrm{ROA}_{3}$ probabilitas $\mathrm{F}$ $(0,000127)$ lebih kecil dari $\alpha=0,05$ dan Model Tobin $\mathrm{Sq}_{3}$ didapatkan nilai probabilitas $\mathrm{F}$ $(0,018780)$ yang kecil dari $\alpha=0,05$. Dengan demikian bahwa variabel independen model $\mathrm{Roa}_{3}$ dan tobinsq ${ }_{3}$ berpengaruh signifikan terhadap nilai kinerja perusahaan.

a. Koefisien Determinan $\left(\mathbf{R}^{2}\right)$

$\mathrm{R}^{2}$ digunakan untuk mengukur seberapa besar proporsi variasi dari variabel independen dan Moderasi secara bersama sama dalam mempengaruhi variabel dependen. Dari hasil pengolahan data ditemukan Model $\mathrm{ROA}_{3}$ nilai $\mathrm{R}^{2}$ sebesar 0,148024 ini bahwa variabel independen dan moderasi (CP) dan variabel control (LV,GP,UMP dan UK mempengaruhi kinerja perusahaan sebesar $14,80 \%$ sedangkan sisanya 85,2 dipengaruhi oleh faktor lain. Dan Model Tobinsq ${ }_{3}$ nilai $\mathrm{R}^{2}$ sebesar 0,227464 ini bahwa variabel independen dan moderasi (CP) dan variabel control mempengaruhi kinerja perusahaan $22,74 \%$ sedangkan sisanya 77,26 dipengaruhi oleh faktor lainnya.

\section{b. T.Statistik}

Dari table diatas dihasilkan nilai koefisien regresi model $\mathrm{ROA}_{3}$ dan Model Tobinsq ${ }_{3}$ untuk pengaruh corporate governance terhadap hubungan antara kebijakan dividen dan kinerja 
perusahaan. Namun pada model ROA 3 KD, DKI, KP,KM, LV, GP, UK, KDXKP dan KDX KM tidak terdapat nilai yang signifikan pada kinerja perusahaan kecuali UMP pada variable control terdapat nilai signifikan 0,0526 yang sama dengan nilai alpa 0,05 setelah itu pada perkalian KDXDKI mendapatkan nilai yang signifikan yang lebih kecil dari alpha yaitu $0,0429<0,05$ yang berarti pada variable moderating dengan hipotesis yang terdiri dari 3 hanya hipotesis ${ }_{2}$ komisaris independen yang berpengaruh pada kinerja perusahaan dengan kesimpulan bahwa pada model $\mathrm{ROA}_{3} \mathrm{H}_{2 \mathrm{a}}$ diterima.

Sedangkan pada model Tobinsq ${ }_{3}$ nilai koefisien regresi moderating dengan hasil dimana KD dengan koefisien sebesar 1,96132 dan p-value lebih kecil dari alpa 0,0038<0,05 dan juga DKI dengan koefisien 0,5202993 dan $\mathrm{p}$-value $0,0069<0,05$ dan juga pada variable control LV dengan koefisien $-0,252182$ dan p-value 0,0001 dan juga pada variable moderating yang melakukan perkalian KDxDKI dengan koefisien -0,05059 dan p-value 0,0016, denga demikian bahwa hipotesis diterima.

\section{PEMBAHASAN}

\section{Pengaruh Kebijakan Dividen terhadap kinerja perusahaan}

Berdasarkan hasil pengujian hipotesis penilaian hipotesis ini bertujuan untuk melihat seberapa besar kontribusi kebijakan dividen pada kinerja perusahaan mampu mesejahterakan para pemegang saham (shareholders, \} selama satu periode.variabel kebijakan dividen terhadap kinerja. Dari tabel 4.1.5.1 diatas menyajikan satu model regresi Return on Asset (ROA) dan Model 1 Tobinsq, yaitu dihasilkan nilai koefisien regresi variabel KD sebesar 0, 0135619 dengan p-value $0,5916>0,05$, pada penelitian ini model regresi pertama tidak signifikan yang berarti variabel independen tidak bias menjelaskan variabel dependen, dan juga model 1 pada variabel tobinsq dengan memasukkan variabel control dengan nilai uji f sebesar 0 , 00085 dan p-value 0,1194 dimana KD tidak signifikan artainya KD tidak bias menjelaskan variabel dependen

Berdasarkan hasil analisis regresi diatas pada modell ROA dan Tobinsq membuktikan bahwa kebijakan dividen tidak terpengaruh terhadap kinerja perusahaan, hal ini tidak sejalan dengan penelitian amidu (2006\} yang menemukan pengaruh kebijakan dividen terhadap kinerja perusahaan yang terdaftar dighana Stock Exchange (GSE) sejalan dengan penelitian marselino wau dan zaitul (2017\} yang menemukan signifikansi kebijakan dividen terhadap kinerja perusahaan yang terdaftar di BEI yang diukur dengan Return On Asset (ROA).

\section{Pengaruh corporate governance terhadap kinerja perusahaan}

Dari table 4.1.5.2 dihasilkan nilai koefisien regresi untuk variabel Corporate governance dan Variabel ROA Model $_{2}$ dimana variabel Dewan Komisaris Independen (DKI) sebesar 0,023 dengan nilai P-value 0,66>0,05 yang berarti bahwa Dewan Komisaris Independen tidak berpengaruh terhadap kinerja perusahaan. Dengan demikian dapat disimpulkan bahwa $\mathrm{H}_{2 \mathrm{a}}$ ditolak artinya pada model kedua bahwa Dewan Komisaris tidak berpengaruh dalam tatakelolah perusahaan yang menimalisir konflik antara principal dan agen.

kemudian nilai hasil koefisien regresi untuk variabel corporate governance yaitu variabel kepemilikan public (KP) sebesar 0,056 dengan nilai P-value 0,1127>0,05 yang berarti bahwa kepemilikan public tidak berpengaruh terhada kinerja perusahaan. Dengan demikian dapat disimpulkan bahwa $\mathrm{H}_{2 \mathrm{c}}$ ditolak artinya pada model kedua kepemilikan public tidak berpengaruh dalam peningkatan kinerja dari pada perusahaan.

Selanjuntnya nilai hasil koefisien regresi untuk variabel corporate governace yaitu variabel kepemilikan manajerial $(\mathrm{KM}\}$ sebesar 0,073 dengan nilai $\mathrm{P}$-value $0,04<0,05$ yang berarti bahwa kepemilikan manajerial berpengaruh terhadap kinerja perusahaan. Dengan demikian dapat disimpulkan bahwa Hipotesis ${ }_{2 b}$ diterima, artinya semakin banyak jumlah saham manajerial, maka semakin tinggi kinerja perusahaan.

Berdasarkan uraian diatas variabel corporate governance yang diukur dengan DKI, KP dan KM dimana DKI dan KP tidak berpengaruh terhadap kinerja perusahaan sedangkan Kepemilikan manajerial (KM) berpengaruh terhadap kinerja perusahaan dimana penelitian ini bertolakbelakang dengan penelitian Desi Apriana (2011\} dimana hasil penelitiannya kepemilikan manajerial tidak berpengaruh terhadap kinerja perusahaan. Dengan kesimpulan bahwa corporate governance yang diukur dengan Kepemilikan manajerial bahwa dengan tatakelolah perusahaan yang baik tentu akan meningkatkan kinerja keuangan dan serta meningkatkan kepercayaan terhadap shareholder.dan juga didukung teori Monk dan Minow, 2008\} corporate governance merupakan pengendali untuk mengatur dan mengelolah perusahaan dengan maksud untuk meningkatkan kemakmuran dan akuntabilitas perusahaan, yang tujuan akhirnya untuk mewujudkan shareholder value. 
Dari table 4.1.5.2 dihasilkan nilai koefisien regresi untuk variabel Corporate governance dan Variabel Tobinsq Model $_{2}$, dimana variabel Dewan Komisaris Independen (DKI) sebesar 0,133 dengan nilai P-value 0,48>0,05 yang berarti bahwa Dewan Komisaris Independen tidak berpengaruh terhadap kinerja perusahaan. Dengan demikian dapat disimpulkan bahwa $\mathrm{H}_{2 \mathrm{a}}$ ditolak artinya pada model kedua pada variabel dependen (Tobinsq) bahwa Dewan Komisaris tidak berpengaruh dalam tatakelolah perusahaan yang menimalisir konflik antara principal dan agen.

Kemudian nilai hasil koefisien regresi untuk variabel corporate governance yaitu variabel kepemilikan public (KP) sebesar 0,225 dengan nilai P-value 0,04<0,05 yang berarti bahwa kepemilikan public berpengaruh terhadap kinerja perusahaan. Dengan demikian dapat disimpulkan bahwa $\mathrm{H}_{2 \mathrm{c}}$ diterima artinya pada model kedua Tobinsq kepemilikan public berpengaruh dalam peningkatan kinerja suatu perusahaan.

Selanjuntnya nilai hasil koefisien regresi untuk variabel corporate governace yaitu variabel kepemilikan manajerial (KM) sebesar 0,030 dengan nilai P-value 0,808>0,05 yang berarti bahwa kepemilikan manajerial tidak berpengaruh terhadap kinerja perusahaan. Dengan demikian dapat disimpulkan bahwa Hipotesis ${ }_{2 b}$ ditolak, artinya bahwa meningkatnya suatu perusahaan kepemilikan manajerial tidak berpengaruh jika variabel dependen Tobinsq .

Berdasarkan uraian diatas variabel corporate governance yang diukur dengan DKI, KP dan KM dimana DKI dan KM tidak berpengaruh terhadap kinerja perusahaan sedangkan Kepemilikan Publik (KP) berpengaruh terhadap kinerja perusahaan dimana penelitian ini didukung olehChermian Eforis (2015 \} dengan judul penelitian pengaruh kepemilikan negara dan kepemilikan public terhadap kinerja keuangan BUMN (studi pada perusahaan BUMN yang Go public tahun 2012-2015) dimana hasil penelitiannya kepemilikan publik berpengaruh terhadap kinerja perusahaan. Dengan kesimpulan bahwa corporate governance yang diukur dengan Kepemilikan publik bahwa dengan tingginya saham public disuatu perusahaan serta merta meningkatkan kinerja dan nilai perusahaan yang diukur dengan tobinsq..

\section{Pengaruh Corporate Governance terhadap hubungan kebijakan dividend dan kinerja perusahaa.}

Table 4.1.5.3 menunjukkan bahwa semua model fit (layak) karena dari 0,05. Sedangkan nilai R square mengalami peningkatan dari Model Roa 3 hingga pada model Tobinsq ${ }_{3}$. Pada model Roa $_{3}$ Hipotesis $\left(\mathrm{H}_{3 \mathrm{a}}\right)$ ditolak dimana nilai signifikansi KDxKP 0,65 besar dari 0,05 dengan arah negative. Selanjuntya, hipotesis $\left(\mathrm{H}_{3 \mathrm{~b}}\right)$ diterima dimana nilai signifikansi $\mathrm{KD}_{\mathrm{X}}$ DKI kecil dari 0,05 sedangkan, hipotesis $\left(\mathrm{H}_{3 \mathrm{c}}\right)$ ditolak dimana nilai signifikansi KDx KP besar dari 0,05 .

Table 4.1.5.3 menunjukkan bahwa semua model fit (layak) karena dari 0,05. Sedangkan nilai R square mengalami peningkatan dari Model Roa ${ }_{3}$ hingga pada model Tobinsq ${ }_{3}$. Pada model tobinsq ${ }_{3}$ Hipotesis $\left(\mathrm{H}_{3 \mathrm{a}}\right)$ ditolak dimana nilai signifikansi KDxKP 0,555 besar dari 0,05 dengan arah negative. Selanjuntya, hipotesis $\left(\mathrm{H}_{3 \mathrm{~b}}\right)$ diterima dimana nilai signifikansi $\mathrm{KD}_{\mathrm{X}} \mathrm{DKI} 0,0016$ kecil dari 0,05 sedangkan, hipotesis $\left(\mathrm{H}_{3 \mathrm{c}}\right)$ ditolak dimana nilai signifikansi KDx KP 0,79 besar dari 0,05. Pada model ketiga tobinsq dimana variabel Kebijakan dividen (KD) signifikan dengan nilai p-value 0,003 kecil dari 0,05 dan juga pada variabel control Umur Perusahaan (UMP) signifikansi dengan nilai p-value 0,024 kecil dari 0,05.

Berdasarkan hasil pengujian pada model Roa $_{3}$ dan Tobinsq menyimpulkan bahwa dimana variabelkebijakan dividen tidak berpengaruh tetapi hasil interaksi moderating KDxDKI atau berpengaruh positif terhadap kinerja perusahaan atau hipotesis $\left(\mathrm{H}_{3 \mathrm{~b}}\right)$ corporate governance memperkuat hubungan kebijakan dividen terhadap kinerja perusahaan. Dimana hasil penelitian ini didukung oleh amidu dan abor, 2006 tentang pengaruh kebijakan dividen terhadap kinerja perusahaa. Dimana penelitian ini dilakukan pada perusahaan perusahaan yang terdaftar di Ghana Stock Exchange (GSE), hasil penelitian ini mendukung bahwa kebijakan dividen adalah relevan terhada kinerja perusahaan yang diukur dengan Return On Asset dan tobinsq. hasil penelitian ini juga didikung oleh (Ben-Nasr, 2015; Bae, Chang dan Kang, 2012) dan setiawan dan phua,2013 tentang pengaruh corporate governance terhada kinerja perusahaan, dan juga penelitian Grove dkk, 2011 dan Nuryanah dan islam, 2011 tentan pengaruh corporate governance terhadap kinerja perusahaan. Dan juga penelitian Marselino wau dan Zaitul (2017) di Simposium Nasional Magister I (Sinmag) tentang pengaruh kebijakan dividen terhadap kinerja perusahaan pertambangan corporate governance sebagai variabel pemoderasi.

Dengan hasil penelitian bahwa corporate governance terhadap hubungan antara kebijakan dividend an kinerja perusahaan berpenagruh positif. Pada variabel control umur perusahaan (UMP) berdampak positif pada model 3, dari model ketiga dapat diambil kesimpulan bahwa perusahaan dengan umur muda lebih cenderung mempunyai kinerja baik dibandingkan dengan perusahaan tua. Dari model ketiga variabel control LV, GP, dan UK tidak ditemukan bukti empiris bahwa besar kecil perusahaan tidak berdampakpada kinerja perusahaan. 
Berdasarkan uraian diatas bahwa pada model $\mathrm{ROA}_{3}$ hasil uji Moderated Regression Analysis menunjukkan bahwa kebijakan dividen tidak berpengaruh terhadap kinerja perusahaan tetapi interaksi antara corporate governancememperkuat hubungan kebijakan dividen terhadap kinerja perusahaan. Sedangkan kinerja perusahaan pada model tobinsq ${ }_{3}$ dimana kebijakan dividen berpengaruh terhadap kinerja perusahaan dan juga interaksi kebijakan dividen memperkuat hubungan terhadap kinerja perusahaan.

\section{KESIMPULAN}

Berdasarkan hasil penelitian dan pembahasan pada bab empat, penulis mengambil kesimpulan penelitian sebagai berikut :

1. Pengaruh Kebijakan Dividen terhadap Kinerja Perusahaan (ROA) pada model ROA $_{1}$ yaitu

a. Kebijakan Dividen (KD) tidak berpengaruh terhadap kinerja perusahaan yang ditunjukkan dengan nilai probabilitas lebih besar dari 0,05 sebesar 0,5916

b. Leverage (LV) tidak mempunyai pengaruh terhadap kinerja perusahaan yang ditunjukkan dengan nilai probabilitas lebih besar 0,05 dari 0,7216. Artinya semakin banyak hutang, maka semakin rendah kinerja perusahaan.

c. Growt Pertumbuhan mempunyai pengaruh yang signifikan terhadap kinerja perusahaan yang ditunjukkan probabilitas 0,05 sama dengan 0,05 artinya

d. Umur perusahaan mempunyai pengaruh yang signifikan terhadap kinerja perusahaan yaitu ditunjukkan probabilitas 0,02 lebih kecil 0,05 artinya

e. Ukuran perusahaan tidak mempunyai pengaruh yang signifikan terhadap kinerja perusahaan yang ditunjukkan probabilitas 0,4914 lebih besar 0,05 artinya

2. Pengaruh Corporate Governance terhadap Kinerja perusahaan (ROA) pada Model $\mathrm{ROA}_{2}$ yaitu

a. Kebijakan Dividen (KD) tidak berpengaruh terhadap kinerja perusahaan yang ditunjukkan dengan nilai probabilitas lebih besar dari 0,3744>0,05 artinya

b. Dewan Komisaris Independen tidak mempunyai pengaruh terhadap kinerja perusahaan yang ditunjukkan nilai probabilitas lebih besar dari 0,66>0,05 artinya.semakin berkurangnya jumlah dewan komisaris, maka semakin rendahnya kinerja perusahaan.

c. Kepemilikan Publik tidak mempunyai pengaruh terhadap kinerja perusahaan yang ditunjukkan nilai probabilitas lebih besar dari 0,11>0,05 artinya

d. Kepemilikan manajerial mempunyai pengaruh sginifikan terhadap kinerja perusahaan yang ditunjukkan nilai probabilitas lebih kecil dari $0,04<0,05$ artinya semakin banyak saham manajerial, maka semakin tinggi kinerja perusahaan.

e. Leverage (LV) tidak mempunyai pengaruh terhadap kinerja perusahaan yang ditunjukkan dengan nilai probabilitas lebih besar 0,05 dari 0,64. Artinya semakin banyak hutang, maka semakin rendah kinerja perusahaan.

f. Growt Pertumbuhan mempunyai pengaruh yang signifikan terhadap kinerja perusahaan yang ditunjukkan probabilitas 0,23>0,05 artinya

g. Umur perusahaan mempunyai pengaruh yang signifikan terhadap kinerja perusahaan yaitu ditunjukkan probabilitas 0,07 lebih kecil 0,05 artinya

h. Ukuran perusahaan tidak mempunyai pengaruh yang signifikan terhadap kinerja perusahaan yang ditunjukkan probabilitas 0,98 lebih besar 0,05 artinya

3. Pengaruh Corporate Governace terhadap hubungan antara Kebijakan Dividend an kinerja perusahaan

a. Kebijakan dividen tidak berpengaruh terhadap kinerja perusahaan yang ditunjukkan probabilitas $0,11>0,05$ artinya

b. Dewan Komisaris Independen tidak berpengaruh terhadap kinerja perusahaan yang ditunjukkan probabilitas $0,10>0,05$ artinya

c. Kepemilikan Publik tidak berpengaruh terhada kinerja perusahaan yang ditunjukkan probabilitas 0,22>0,05 artinya

d. Kepemilikan Manajerial tidak berpengaruh terhadap kinerja perusahaan yang ditunjukkan probabilitas $0,44>0,05$ artinya

e. Leverage tidak berpengaruh terhadap kinerja perusahaan yang ditunjukkan probabilitas $0,68>0,05$ artinya

f. Growt perusahaan tidak berpengaruh terhadap kinerja perusahaan yang ditunjukkan probabilitas $0,21>0,05$ artinya 
g. Umur perusahaan mempunyai pengaruh terhadap kinerja perusahaan yang menunjukkan nilai probabilitas 0,05 sama dengan 0,05 artinya

h. Ukuran perusahaan yang diukur dengan total asset dan total hutang tidak berpengaruh terhadap kinerja perusahaan yang menunjukkan probabilitas 0,70>0,05 artinya

i. Interaksi kebijakan dividend an kepemilikan public tidak berpegaruh terhadap kinerja perusahaan yang menunjukkan probabilitas $0,65>0,05$ artinya

j. Interaksi kebijakan dividen dan dewan komisaris independen berpengaruh terhadap kinerja perusahaan yang menunjukkan probabilitas 0,04>0,05 artinya

k. Interaksi kebijakan dividend an kepemilikan manajerial tidak berpengaruh terhadap kinerja perusahaan yang menunjukkan probabilitas 0,22>0,05 artinya.

\section{SARAN}

Berdasarkan hal tersebut maka penulis menyarankan pada penelitian sejenis dimasa yang akan datang dan bahkan dilanjutkan dengan variabel moderating serta menambahkan variabel penelitian yang sekiranya relevean mampu memprediksi kinerja perusahaan. Hal ini dilakukan dengan tujuan agar hasil penelitian menjadi lebih kompleks dan akurat. Namun pada penelitian ini juga dilakukan hanya pada satu perusahaan utama yang listed di BEI, disarankan pada penelitian yang akan datang bisa diperbandingkan antara perusahaan utama, misalnya perusahaan manufaktur, perusahaan infrastruktur dan sebagainya.

\section{DAFTAR PUSTAKA}

Akhmad Syakhroza (2002), "Mekanisme Pengendalian Internal dalam melakukanAssesment terhadap Pelaksanaan Good Corporate Governance".Manajemen Usahawan Indonesia, No. 08/Th. XXXI, Agustus.

(2003), "Teori Corporate Governance". Manajemen Usahawan Indonesia,no. 08/Th. XXXII, Agustus

Amidu, M., dan Abor, J. (2006). Determinants of dividend payout ratios in Ghana, The Journal of Risk Finance, 7(2), 136-145.

Berle, A., dan Means, G. (1932). The Modern Corporation and private propert. Mac-Millan, New York.

Brainard, W, and Tobin, J, 1968. "Pitffals inFinancial Model Building",AmericanEconomic Review, Vol. 58(2), pages 99-122.

Bhattacharya, S. (1979), "Imperfect Information, Dividend Policy, and "The Bird inthe Hand" Fallacy". Bell Journal of Economics, Vol. 10: pp. 259-270

Bambang Riyanto L.S. (2003), "Corporate Governance di Indonesia: A General Overview". Makalah Disampaikan di Forum Diskusi Ekonomi Putaran1.Universitas Atma Jaya, Yogyakarta. 24 April.

Boediono, Gideon SB. (2005). Kualitas Laba : Studi Pengaruh Mekanisme Corporate Governance dan Dampak Manajemen Laba dengan Menggunakan Analisi Jalur. Simposium Nasional Akuntansi VIII Solo, 15-16 September 2005.

Brigham, Eugene F. dan Houston Joel F. (2006), "Dasar-Dasar ManajemenKeuangan Jilid 1". Alih Bahasa Ali Akbar Yulianto, Edisi Kesepuluh,Penerbit Salemba Empat, Jakarta.

Bae, S., C., Chang, K., dan Kang, E. (2012). Culture, corporate governance and dividend policy: international evidence, The journal of financial research, 35(2), 289-316.

Ben-Nasr, H. (2015). Government ownership and dividend policy: evidence from Newly privatised firm, Journal of Business \& Accounting, 42(5/6), 665-704

Bringham, E., F., dan Houston, J., F. (2016). Fundemental of Financial Management, 14th edition, Cangage Learning, Boston, USA.

Easterbrook, F., H. (1984).Two Agency-Cost Explanations of Dividends, the American Economic Review, 74(4), 650-659.

Fiakas, D, 2005. Tobin's q: Valuing Small Capitalization Companies, Crystal EquityResearch, April.

Gujarati, D.N. (1995). Basic Econometrics, McGraw-Hill Inc

Grove, H., Patelli, L., Victoravich, L. M., dan Xu, P (Tracy) (2011). Corporate Governance and Performance in the Wake of the Financial Crisis: Evidence from US Commercial Banks. Corporate Governance: An International Review, 19(5), 418-436.

Herman Darwis, (2009). Corporate Governance terhadap Kinerja Perusahaan. Vol. 12. No 3, September 2009 
Joko sukendro dan C.Ambar Pujiharjanto (2012) “ Pengaruh Kebijakan Dividen terhadap Perusahaan di Indonesia (Study Empirik pada perusahaan-perusahaan Non Keuangan yang terdaftar di BEI dengan Probabilistic Regresi Model). Vol.1. 1 Desember 2012

Jensen, M. dan W. Meckling (1976), "Theory of the Firm: Managerial Behavior, Agency, and Ownership Structure". Journal of Financial Economics. Vol.3. (October): pp. 305-360.

Kaplan, R. S., dan Norton, D., P. (1992). The Balanced Scorecard - measures that drive performance, Harvard Business Review, 70(7/8), 172-180.

Klapper, L.F. \& Love, I. (2002). Corporate Governance, Investor Protection,and Performance in EmergingMarkets.

Long, John B., Jr. (1978), “The Market Valution of Cash Dividends: Case toConsider”. Journal of Financial Economics, Vol. 6: pp. 235-264.

Lang, L.H.P., Stulz, R.M, and Walkling, 1989. "Managerial Performance, Tobin's q, and the Gains from Successful Tender Offers". Journal of Financial Economics (September), 137154.

La-porta, R., Lopez-de-silanes, F., Shleifer, A., dan Vishney, R. (2000). Investor protection and corporate governance, Journal of Financial Economics, 58, 3-27

Monks, R. A. G., \& Minow, N. (2008). Corporate Governance (4th edition) Wiley, Chichester.

Miller, M., H., dan Modigliani, F. (1961). Dividend policy, growth, and the valuation of share, the Journal of Business, 34(4), 411-433

Meixell, M., dan Lauma, P. (2015). Stakeholder pressure in sustainable supply chain management. a systematic review, International journal of physical

Marselino Wau,dan Zaitul, (2017). Pengaruh Kebijakan Dividen terhadap kinerja perusahaan pertambangan, corporate governance sebagai variabel permoderasi. Simposium Nasional Magister I, Padang, 23 Oktober 2017.

La Rocca, Mauritio, 2007, The influance of corporate governance on the relation between capital structure and Value, Corporate Governance,Vol. 7 No. 3, pp. 312-325, Emerald Group Publishing Limited, ISSN 1472-0701.

Richard, P., J., Devinney, T., M., Yip, G., S., dan Johnson, G. (2009). Measuring Organizational Performance: Towards Methodological Best Practice, Journal of Management, 75(3), 718-804

Setiawan, D., dan Phua, L., K. (2013). Corporate governance and dividend policy in Indonesia, Business strategy series, 14(5/6), 135-143.

Sekaran, Uma. (2011). Research Method For Business. Jakarta : Salemba Empat.

Sugiyono. (2008). Metode Penelitian Bisnis. Bandung : Alfabeta..

World Bank (1999), "Corporate Governance: A Framework for Implementation 